\title{
The Diversity of Ferns (Pteridophyta) at Pundong Japanese Cave, Bantul, Yogyakarta
}

\author{
Zuchrotus Salamah ${ }^{1 *}$ Hadi Sasongko ${ }^{2}$ Risdianti Novida ${ }^{1}$
}

\author{
${ }^{1}$ Biology Education Department, Faculty of Teacher Training and Education, Ahmad Dahlan University, Yogyakarta, \\ Indonesia \\ ${ }^{2}$ Biology Department, Science and Applied Technology Faculty, Ahmad Dahlan University, Yogyakarta, Indonesia \\ *Corresponding author. zuchrotus.salamah@pbio.uad.ac.id
}

\begin{abstract}
Yogyakarta Special Region is one of the regions with many historical relics and strong cultural exposure. These assets are widely used as a tourism attraction as well as education. One of the relics, widely known as Pundong Japanese Cave, is one of the mentioned historical tourism attractions in which overgrown by ferns. The objective of this research is to determine the variety of ferns grown on this particular area. The type of this research is exploration, by doing plotless exploration-investigation; the subject of this research is the Pundong Japanese Cave site, and the object is ferns grown within the site location. Data is analysed using descriptive method, analysing the morphology of roots, stem, leaves, sorus, and the leaves cell. Result of this research showing that there are 10 species found at Pundong Japanese Cave, which are: (1) Pteris vittata Linnaeus., (2) Adiantum philippense Linnaeus., (3) Adiantum capillus-veneris Linnaeus. (4) Pityrogramma calomelanos L., (5) Thelypteris sp., (6) Nephrolepis cordifolia (Linnaeus) C. Presl, (7) Pneumatopteris sp., (8) Pyrrosia longifolia (N.L.Burman)., (9) Drynaria quercifolia (Linnaeus) J.Smith, and (10) Selliguea hastata (Thunberg) Fraser-Jenkins.

Keywords: Ferns, diversity, Yogyakarta, Japanese cave.
\end{abstract}

\section{INTRODUCTION}

Ferns are one of the plants that have distinct cormus, in which the part of its plant structure are distinguishable in three main part: roots, stems, and leaves. Ferns do not have seeds; the reproduction organ of this plant is spores. Ferns have some classes, which are Psilophytinae, Lycopodiinae, Equisetinae and Filicinae. So far, there are 10,000 kinds of ferns in total around the world and 1,300 of them grown in Indonesia[1].

There are few researches on ferns that have been conducted previously. These researches are about the inventory of ferns species (Pteridophyta) at Sebelah Darat Forest, West Borneo[2], the diversity of ferns (Pteridophyta) along the Selo Hiking Trails, Merbabu National Park, Central Java [3], pteridophyte identification at Piket Nol, Lumajang as a leaning material in Biology [4], and about the diversity of ferns within the ancient volcano of Nglanggeran area [5]. However, the research about ferns diversity observed at cave environment has never been done before, especially a research performed on a historical cave with a tourism potential in Yogyakarta.

Pundong Japanese Cave situated at Seloharjo Village, Pundong, Bantul, Yogyakarta. There are eighteen caves located scattered within the complex with the area of 12 hectares and $350 \mathrm{mdpl}$ altitude [6]. According to the observation, there are no record of researches about the inventory of ferns (Pteridophyta) at Pundong Japanese
Cave complex. Cave is a habitat for various flora and fauna which live in a humid and obscure area. The humid and obscure environment condition affects the diversity of biota live at the cave area. The fact that only the biota which is able to adapt in this area will survive and maintain its reproductivity resulting in a distinctive, unique, and specific biota. The major factor influences the environment condition is the low light intensity in which affecting the surrounding temperature, humidity, and other environmental factors. Based on these interesting backgrounds, the objective of exploration can be determined, which is to determine the species of ferns grow in this unique area.

\section{MATERIAL AND METHODS}

This research is an explorative research, conducted on April to September 2019. The location of this research taken place on Pundong Japanese Cave complex, Bantul, Yogyakarta. There are total eighteen caves in the area and the exploration was performed on all locations, from the 1 st to 18 th caves. Ferns identification were conducted at Universitas Ahmad Dahlan and Universitas Gadjah Mada, while the microscope slides of the specimens were completed at Biology Laboratory, Universitas Ahmad Dahlan. Figure 1 below shows the location and the map of the Japanese Caves complex. 


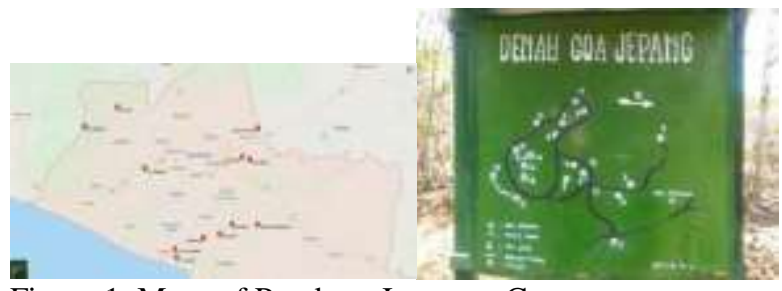

Figure 1. Maps of Pundong Japanese Caves

Tools and equipment used in this research are as follows: digital camera, map of location, stationery, scissors, thermometer, hygrometer, soil tester, lux meter, altimeter, wattle, shovel, flacon tubes, cutter, binocular microscope, stereo microscope, optilab, beaker glass, brushes, dropper, and laptop. The identification process of ferns used a handbook titled Flora of China.

Materials used for this research are ferns samples collected from the site, aquadest, chloral hydrate substance, label sticker, unused newspaper papers, tapes, and plastic bags. Specimen collection in this observation used plotless exploration method, by exploring the examination site thoroughly. Environmental parameters measured in this research are temperature, humidity, light intensity, and soil $\mathrm{pH}$ level.

Samples that has been collected are being cleaned using brushes. Examination on morphology characteristics of ferns is conducted, which includes observation on roots (types, colours, and surfaces), stems (shapes, colours, surfaces, rhizomes, and branches), leaves (singular/compound leaves, lengths, widths, circumscriptions, apex folii, basis folii, skeletons, margin, types, and colours). Observation on ferns leaves cells are conducted through microscope slides that were made using leaf clearing method [7]. Observation on cells features is completed using Optilab. The features observed are cell shapes, length, width, stomata, and trichomes. Sorus observation is being done by examining colours, shapes, and sorus location. All data are analysed using descriptive method.

\section{RESULT AND DISCUSSION}

\subsection{Result}

The cave complex observed as the site of this research is a tourism attraction located in Pundong, Bantul. It has 18 caves scattered within the conservation area. This cave complex considered as one of the attractive tourism destinations as it has a rich historical background and a direct view to Parangtritis beach and shoreline is overseen from this area. Based on the measurement on the environmental condition of this area, the acquired parameters are $\mathrm{pH}$ level of $5.8-6.8$, means that the soil is relatively acid close to alkali which is a suitable condition for ferns to grow. The soil within the area is dominated by gravel and a hard soil structure. Humidity levels are $10 \%$ $40 \%$ for the soil and $65 \%-73 \%$ for the air. Light intensity is 579-2380 Lux, measured on a daylight. During the morning and late afternoon, the humidity level is higher and the temperature and light intensity are lower.

Identification and observation result show that there are 10 species of ferns grow within the Pundong Japanese Cave area. They are Pteris vittata Linnaeus., Adiantum philippense Linnaeus., Adiantum capillus-veneris Linnaeus., Pityrogramma calomelanos L., Thelypteris sp., Nephrolepis cordifolia (Linnaeus) C. Presl, Pneumatopteris sp., Pyrrosia longifolia (N.L.Burman),, Dynaria quercifolia (Linnaeus) J.Smith, Selliguea hastata (Thunberg) Fraser-Jenkins. Table 1 shows the lists of species, family, and habitat from all of the discovered species of ferns found in the area.

Table 1. Species, Family and Habitat of Ferms Grow at Pundong Japanese Cave

\begin{tabular}{|c|c|c|c|}
\hline No & Species & Family & Habitat \\
\hline 1 & Pteris vittata $\mathrm{L}$. & Pteridaceae & Terrestrial \\
\hline 2 & $\begin{array}{l}\text { Adiantum } \\
\text { philippense L. }\end{array}$ & Pteridaceae & Terrestrial \\
\hline 3 & $\begin{array}{l}\text { Adiantum } \\
\text { capillus-veneris } \\
\text { L. }\end{array}$ & Pteridaceae & Terrestrial \\
\hline 4 & $\begin{array}{l}\text { Pityrogramma } \\
\text { calomelanos L. }\end{array}$ & Pteridaceae & Terrestrial \\
\hline 5 & Thelypteris sp. & Thelypteridaceae & Terrestrial \\
\hline 6 & $\begin{array}{l}\text { Nephrolepis } \\
\text { cordifolia } \\
\text { (Linnaeus) C. } \\
\text { Presl }\end{array}$ & Nephrolepidaceae & Terrestrial \\
\hline
\end{tabular}

7 Pneumatopteris Thelypteridaceae Grow on rock surface

sp.

\begin{tabular}{llll}
\hline 8 & $\begin{array}{l}\text { Pyrrosia } \\
\text { longifolia } \text { (N. L. } \\
\text { Burman) }\end{array}$ & Nephrolepidaceae & Epiphyte \\
\hline 9 & $\begin{array}{l}\text { Drynaria } \\
\text { quercifolia } \\
\text { (Linnaeus) } \\
\text { Smith }\end{array}$ & J. & \\
\hline 10 & $\begin{array}{l}\text { Selliguea } \\
\text { hastata } \\
\text { (Thunberg) } \\
\text { Fraser-Jenskins }\end{array}$ & Polypodiaceae & Grow on rock \\
& & surface \\
\hline
\end{tabular}


Observation on morphology features of leaves, roots, stems, and sorus are conducted afterwards. Result of the data analysis listed on Table 2.

Table 2. Dimension, Circumscription, and Leaves Colour Observation Result

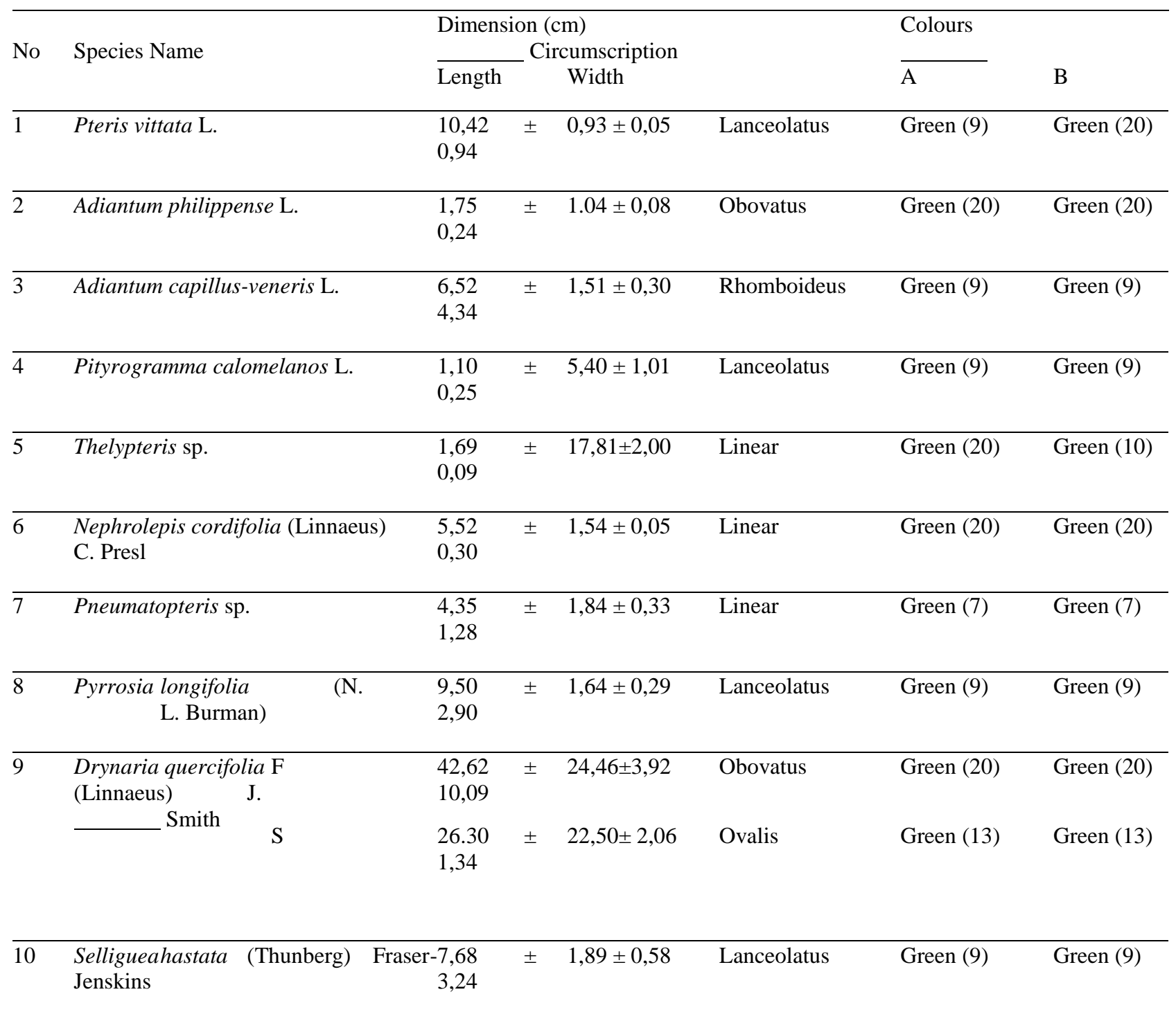

Notes: A: Top, B: Bottom, Green (7): Jade, Green (9): Fern, Green (20): Sea, Green (13): Mint

Table 3. Structural Features of Fern Leaves

\begin{tabular}{|c|c|c|c|c|c|c|c|c|}
\hline \multirow{3}{*}{ No } & \multicolumn{3}{|c|}{ Folium } & \multirow[b]{2}{*}{ Apex } & \multirow{2}{*}{\multicolumn{2}{|c|}{ Margin }} & \multirow{3}{*}{ Nervatio } & \multirow{3}{*}{ Type } \\
\hline & Species Name & & Basis & & & & & \\
\hline & & $\mathrm{S}$ & $\mathrm{C}$ & & & & & \\
\hline 1 & Pteris vittata $\mathrm{L}$. & $\sqrt{ }$ & Truncatus & Acutus & Serratus & Pinnatus & Imparipinnatus & 1 \\
\hline 2 & Adiantum philippense L. & $\sqrt{ }$ & Obtusus & Retusus & Lobatus & Parallelus & Imparipinnatus & 2 \\
\hline 3 & $\begin{array}{l}\text { Adiantum } \\
\text { veneris } \mathrm{L} \text {. }\end{array}$ & & Obtusus & Emarginatus & Entire & Parallelus & Tripinnatus & 3 \\
\hline 4 & $\begin{array}{l}\text { Pityrogramma } \\
\text { calomelanos L. }\end{array}$ & $\sqrt{ }$ & Obtusus & Acuminatus & $\begin{array}{l}\text { Pinnati } \\
\text { Partitus }\end{array}$ & Pinnatus & Imparipinnatus & 4 \\
\hline$\overline{5}$ & Thelypteris $\mathrm{sp}$. & $\sqrt{ }$ & Truncatus & Acutus & Serratus & Pinnatus & Imparipinnatus & 5 \\
\hline
\end{tabular}




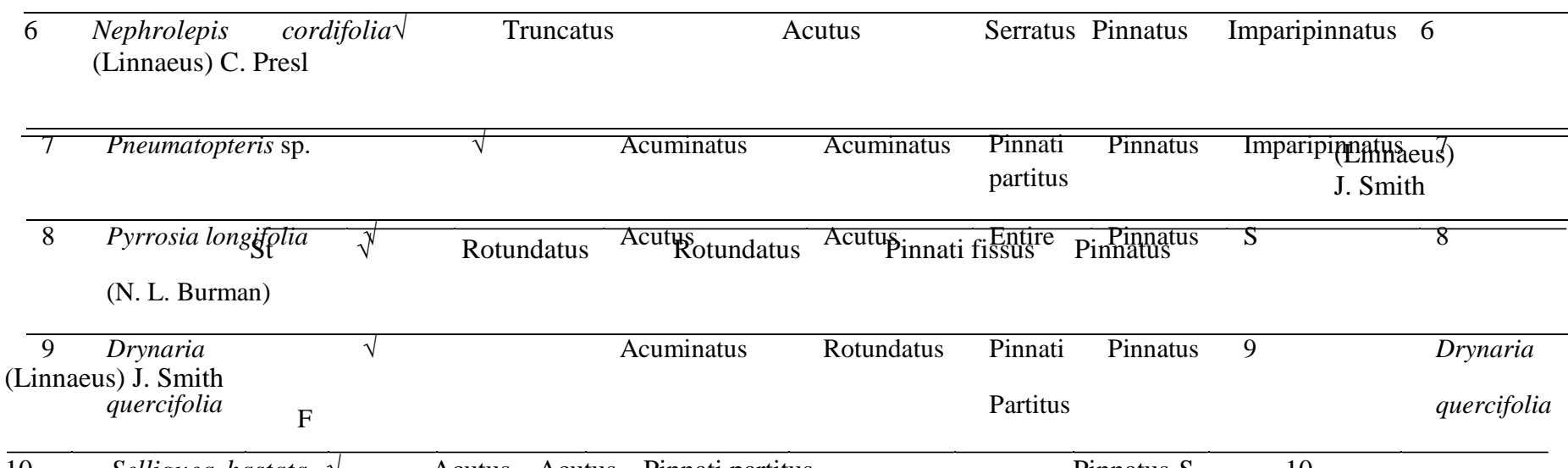

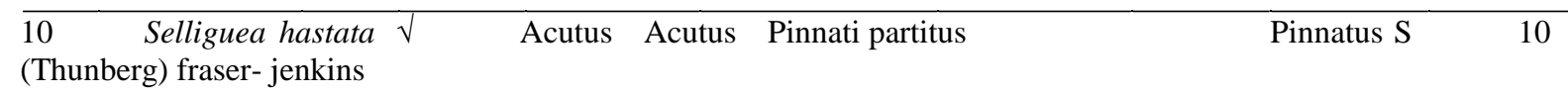

\section{Notes: S: Simplex, C: Compositum, St: Steril}

Table 4. Sorus Observation Result

\begin{tabular}{|c|c|c|c|c|}
\hline No & Species & Colour & Shape & Location \\
\hline 1 & Pteris vittata L. & Brown (11) & Linear & Edge of leaf underside surface \\
\hline 2 & Adiantum philippense L. & Brown (11) & Linear & Edge of leaf upperside surface \\
\hline 3 & Adiantum capillus-veneris L. & Brown (2) & Linear & Edge of the lower part of leaf surface \\
\hline 4 & Pityrogramma calomelanos L. & White & Circular & $\begin{array}{l}\text { Scattered evenly on the lower part of leaf } \\
\text { underside surface }\end{array}$ \\
\hline 5 & Thelypteris sp. & Brown (4) & Circular & Lower edge of leaf \\
\hline 6 & $\begin{array}{l}\text { Nephrolepis cordifolia } \\
\text { (Linnaeus) C. Presl }\end{array}$ & Brown (11) & Circular & Between leaf structure, close to edge of leaf \\
\hline 7 & Pneumatopteris sp. & Brown (8) & Linear & Lower edge of leaf along the blade crease \\
\hline 8 & Pyrrosia longifolia (N. L. Burman) & Brown (1) & Circular & $\begin{array}{l}\text { Scattered clumping lower part of leaf surface at } \\
\text { the tip }\end{array}$ \\
\hline 9 & $\begin{array}{l}\text { Drynaria quercifolia (Linnaeus) } \\
\text { J. Smith }\end{array}$ & Brown (4) & Circular & Between leaf veins lower part of leaf surface \\
\hline 10 & $\begin{array}{l}\text { Selliguea hastata (Thunberg) Fraser } \\
\text { Jenskins }\end{array}$ & -Brown (11) & Circular & At the center of the leaf branch structure \\
\hline
\end{tabular}

Notes: (1): Brown, Brown (2): Cedar, Brown (4): Brunete, Brown (8): Chocolate, Brown (11) : Caramel 
Table 5. Result of Epidermis and Stoma cells

\begin{tabular}{|c|c|c|c|c|c|c|c|}
\hline \multirow[t]{2}{*}{ No } & \multirow[t]{2}{*}{ Name } & \multicolumn{2}{|c|}{ Upper Epidermis $(\mu \mathrm{m})$} & \multicolumn{2}{|c|}{ Lower Epidermis $(\mu \mathrm{m})$} & \multicolumn{2}{|c|}{ Stomata $(\mu \mathrm{m})$} \\
\hline & & $\mathrm{L}$ & W & $\mathrm{L}$ & W & $\mathrm{L}$ & W \\
\hline 1 & Pteris vittata $\mathrm{L}$. & $48,2+7,8$ & $27,9+9,2$ & $26,8+7,05$ & $12,4 \pm 3,6$ & $12,1 \pm 0,6$ & $7,0 \pm 0,5$ \\
\hline 2 & Adiantum philippense $\mathrm{L}$. & $39,2+9,3$ & $11,7+4,6$ & $46,0+7,1$ & $14,3 \pm 2,5$ & $12,4 \underline{ \pm} 1,6$ & $9,5 \pm 0,8$ \\
\hline 3 & Adiantum capillus veneris $\mathrm{L}$. & $35,3+5,6$ & $8,9+7,3$ & $26,8+8,2$ & $9,2 \pm 1,9$ & $6,9 \pm 0,4$ & $5,7 \pm 0,6$ \\
\hline 4 & Pityrogramma calomelanos $\mathrm{L}$. & $75,8+10,0$ & $14,1+2,1$ & $60,0+6,7$ & $18,7 \pm 0,9$ & $18,5 \pm 2,0$ & $11,0 \pm 0,9$ \\
\hline 5 & Thelypteris sp. & $16,6+2,6$ & $12,1+1,6$ & $19,9+5,5$ & $9,2 \pm 5,5$ & $10,8 \pm 0,9$ & $6,2 \pm 0,3$ \\
\hline 6 & $\begin{array}{l}\text { Nephrolepis cordifolia } \\
\text { (Linnaeus) C. Presl }\end{array}$ & $33,8+7,2$ & $16,9+4,9$ & $31,8+6,1$ & $11,8 \pm 3,1$ & $16,0 \pm 1,7$ & $10,4 \pm 0,9$ \\
\hline 7 & Pneumatopteris sp. & $43,4+5,9$ & $19,6+5$ & $69,4+2,7$ & $16,8 \pm 3,1$ & $17,6 \pm 1,1$ & $7,9 \pm 0,7$ \\
\hline 8 & Pyrrosia longifolia (N.L. Burman) & $15,0+3,1$ & $10,2+1,9$ & $18,8+2,8$ & $12,1 \pm 2,8$ & $10,7 \pm 0,7$ & $9,8 \pm 0,8$ \\
\hline 9 & $\begin{array}{l}\text { Drynaria quercifolia } \\
\text { (Linnaeus) J. Smith. }\end{array}$ & $33,8+6,3$ & $22,0+5,3$ & $26,1+13,3$ & $16,1 \pm 4,7$ & $15,5 \pm 1,5$ & $12,2 \pm 0,8$ \\
\hline 10 & $\begin{array}{l}\text { Selliguea hastata (Thunberg) } \\
\text { Fraser-Jenkins }\end{array}$ & $25,3+3,8$ & $15,7+3,4$ & $25,1+1,9$ & $13,3 \pm 2,3$ & $13,5 \pm 1,0$ & $9,9 \pm 0,3$ \\
\hline
\end{tabular}

Notes: L(Length), W(Width) 


\subsection{Discussion}

The results showed that in the area of Gua Jepang there are ferns which belong to the true fern group, obtained 10 species from different families (Table 1). Types belonging to the family Pterydaceae was found the most compared to other families, namely Nephrolepidaceae, Thelypteridaceae, and Polypodiaceae. Habitat from ferns found in terrestrial, rocks, and epiphytes in trees, is in accord with the characteristics of the rocky cave environment and overgrown with many trees. The cave area is a tourist destination located in the Dusun of Ngreco and Poyahan in Seloharjo Village, Pundong Bantul Yogyakarta

Fern species in the Gua Jepang area can be attributed to abiotic factors such as air humidity, light intensity, air temperature, and soil $\mathrm{pH} /$ substrate[8]. Most of the ferns found are on soil and rock substrates, according to the characteristics of Pterydaceae [9] and only one species found epiphytes namely Pyrrosia longifolia (N.L.Burman).

The Green color of leaves, shows that all leaves can do photosynthesis. Leaf size varies, Drynaria quercifolia (Linnaeus) J. Smith has the largest size (Table 2.). Pteris vittata $\mathrm{L}$. has a lanceolate leaf shape and is a terrestrial nail, a slender leaf stalk [10]. Most ferns were found to have compound leaf types (Table 3). Drynaria quercifolia (Linnaeus) J. Smith has fertile and sterile leaves that have different shapes, fertile leaves have circular shape of breech eggs while the sterile leaves are egg round.

Pityrogramma calomelanos L. grows upright, has a monopodial branching and blackish brown stem color. The leaves have a blunt base, a pointed tip, a soft texture with a slippery upper and lower surface and a white grain at the bottom of the leaf. The leaf color is dark green and odd pinnate sporophile shape, has white powder-shaped spores.

\section{CONCLUSION}

Pterydophyes di Kawasan wisata Gua Jepang Pundong diperoleh 10 spesies yaitu Pteris vittata Linnaeus., Adiantum philippense Linnaeus., Adiantum capillusveneris Linnaeus., Pityrogramma calomelanos L., Thelypteris sp., Nephrolepis cordifolia (Linnaeus) C. Presl, Pneumatopteris sp., Pyrrosia longifolia (N.L.Burman)., Dynaria quercifolia (Linnaeus) J.Smith, Selliguea hastata (Thunberg) Fraser-Jenkins.

\section{REFERENCES}

[1] Sandy, Susan, Ari., Pantiwati, Yuni., Hudha, Atok, Miftachul., dan Latifa, Roimil. 2016. "Keanekaragaman Jenis Tumbuhan Paku (Pteridophyta) Di Kawasan Air Terjun Lawean Sendang Kabupaten Tulungagung". Prosiding Seminar Nasional II Tahun 2016, Kerjasama Prodi Pendidikan Biologi FKIP dengan Pusat
This result is almost the same as the identification of Pityrogramma calomelanos $\mathrm{L}$ in the forest area of the village of Kalingkau, Kab. Batola [11].

Sorus is a collection of sporangia in true ferns, and varies in shape, color, location. Pyrrosia longifolia (N. L. Burman) has a circular sorus, scattered clustered at the bottom of the leaf surface at the tip of the leaf or the entire leaf without indusium. The dead leaves are separated from the rhizome, single, elongated shape and the young one is full of star strands. Pyrrosia longifolia Epiphytes or on wet rocks [12]. Drynaria quercifolia sorus located between the veins under the leaf surface. Sorus is generally located on the underside of the leaf surface, but varies in its position on the edge of the leaf, in the part close to the main leaf structure, close to the branch structure and is scattered.

Epidermal cells are clearly observed in all variants, Pityrogramma calomelanos $\mathrm{L}$. has the largest size of the upper epidermis compared to the others with an average of $75.8+10.0 \mu \mathrm{m}$. Stomata is a porous flanked by two neighboring cells, Pityrogramma calomelanos L. has an anomocytic type stoamata [13]. with the characteristics of kidney-shaped cover cells, surrounded by neighboring cells in an indeterminate number and neighboring cells form the same as epidermal cells. Cell size, stomata, stoma density and trichome can be affected by the natural conditions in which the plant grows [14]. Another feature that can be used to distinguish between types is the existence of trichomes, trichomes are epidermal derivates that serves to reduce evaporation, protect cells from heat, and interference from other organisms. Pyrrosia longifolia (N.L. Burman) has a scaly trichome with a widening base. Pyrrosia longifolia (N.L. Burman) found in the province of Riau has flattened edge scales, while the other three types of edge scales resemble that of hair with loose ends [15].

Studi Lingkungan dan Kependudukan (PSLK) Universitas Muhammadiyah Malang, 26 Maret 2016. Hal 835.

[2] Hasibuan, Hotmatama, Rizalinda dan Elvi Rusmiyanto P.W. 2016. "Inventarisasi Jenis Paku-Pakuan (Pteridophyta) Di Hutan Sebelah Darat Kecamatan Sungai Ambawang Kalimantan Barat”. Protobiont. Volume 5, No. 1 Hal 46-58.

[3] Astuti, Fitri Kusuma, Murningsih dan Jumari. 2017. "Keanekaragaman Jenis Tumbuhan Paku (Pteridophyta) Di Jalur Pendakian Selo Kawasan Taman Nasional Gunung Merbabu Jawa Tengah". Jurnal Biologi. Volume 1, No. 1 Hal. 1-6.

[4] Jannah, Miftakhul, Wahyu Prihanta dan Eko Susetyorini. 2015. "Identifikasi Pteridophyta Di Piket Nol Pronojiwo Lumajang Sebagai Sumber Belajar Biologi". Jurnal Pendidikan Biologi Indonesia. Volume 1, No. 1 Hal. 89- 98.

[5] Handayani, Trikinasih, dan Puput Sugiarti. 2017. "Keanekaragaman JenisTumbuhan Paku Di Kawasan Gunung Api Purba Nglanggeran 
Sebagai Sumber Belajar Biologi SMA Kelas X Materi Keanekaragaman Hayati”. Prosiding Seminar Nasional Kedua Pendidikan. Hal. 683692.

[6] BPCB DIY. 2016. Kegiatan Herinventarisasi Cagar Budaya di Kecamatan Pundong Kabupaten Bantul. Yogyakarta: BPCB DIY.

[7] Salamah, Agung Budiantoro, Haris Setiawan, Nurul. 2019. Petunjuk Praktikum Mikroteknik. Yogyakarta: Laboratorium Biologi UAD.

[8] Ceri Bunia, Lovadi Irwan dan Linda Riza. 2014. "Keanekaragaman Jenis Paku-Pakuan (Pteridophyta) di Mangrove Muara Sungai Peniti Kecamatan Segedong”. Jurnal Protobiont, Protobiont 2014 Vol 3 (2): 240 - 246.

[9] Arini, Dwi., Irawati, Diah., dan Kinho, Julianus. 2012. "Keragaman Jenis Tumbuhan Paku (Pteridophyta) Di Cagar Alam Gunung Ambang Sulawesi Utara". Jurnal Info BPK Manado Volume 2 No 1, Juni 2012. Hal:18-19.

[10] Suhono, Budi. 2012. Ensiklopedia Biologi Dunia Tumbuhan Paku. Jakarta: PT Lentera Abadi.

[11] Nurdiyanah, Aulia Ajizah, Mahrudin. 2016.
"Keanekaragaman Tumbuhan Paku (Pteridophyta) Di Kawasan Hutan Desa Palingkau Kabupaten Batola Dalam Pengembangan Handout Biologi SMA”. Jurnal Tugas Akhir Mahasiswa. Hal. 47-50.

[12] Hasibuan, Hotmatama, Rizalinda dan Elvi Rusmiyanto P.W. 2016. "Inventarisasi Jenis Paku-Pakuan (Pteridophyta) Di Hutan Sebelah Darat Kecamatan Sungai Ambawang Kalimantan Barat". Protobiont. Volume 5, No. 1 Hal 46-58.

[13] Arianto, 2016. Taksonomi Polypodiaceae Ditinjau Dari Type Stomata. Prosiding Seminar Nasional XI Pendidikan Biologi FKIP UNS.

[14] Sasongko dan Zuchrotus Salamah, 2016. Studi Komparatif Struktur Daun Cabai Rawit yang Hidup di Daerah Samas dan Gunung Kidul dengan Tingkat Cekaman Salinitas yang Berbeda. Prosiding Symbion Pendidikan Biologi Universitas Ahmad Dahlan.

[15] Sofiyanti, Mayta Novaliza Isda, 2018. Kajian Morfologi dan Mikromorfologi (Sisik serta Trikoma) 4 Jenis Pyrrosia Mirb. (Polypodiaceae) Di Provinsi Riau. Jurnal Biologi Tropis. 